\title{
BENZODIAZEPINE USE AMONG EMPLOYEES OF A PRIVATE COMPANY
}

\author{
Alide Salazar Molina ${ }^{1}$ \\ Adriana Inocenti Miasso ${ }^{2}$
}

Salazar Molina A, Miasso AI. Benzodiazepine use among employees of a private company. Rev Latino-am Enfermagem 2008 maio-junho; 16(especial):517-22.

This study aimed to identify variables associated to the consumption of benzodiazepine among workers of a private company in the VIII Region, Chile. This is a cross-sectional and correlative study. Study population: 40 employees of a private company. The instruments included a questionnaire on socio-demographic variables and a benzodiazepine questionnaire. There was no record of benzodiazepine consumption at the moment of the study. Twenty percent (20\%) of the interviewees had already used benzodiazepine in the past, whereas, half of them (10\%) in the last year. The bivariate analysis of the last year consumption of benzodiazepine with work hours variables showed no significant relation $(p=0.073)$. No association was found between benzodiazepine consumption and socio-demographic variables among the study participants.

DESCRIPTORS: receptors, GABA-A; workers; mental health

\section{CONSUMO DE BENZODIAZEPINAS EN TRABAJADORES DE UNA EMPRESA PRIVADA}

El propósito de este estudio fue identificar las variables asociadas al consumo de benzodiazepinas en población trabajadora de una institución privada de la VIII Región, Chile. Diseño cuantitativo, transversal y correlacional. Población del estudio: 40 trabajadores de una empresa privada de la VIII Región, Chile. Instrumentos recolectores de datos. Cuestionario de variables biosociodemográficas y Cuestionario de benzodiazepinas. No se registró consumo de benzodiazepinas al momento del estudio. 20\% de los entrevistados tenía antecedentes de consumo de benzodiazepinas en el pasado, de ellos la mitad (10\%) en el último año. El análisis bivariado del consumo de benzodiazepinas en el último año con variables del trabajo sólo mostró una relación débilmente significativa $(p=0,073)$ con la jornada de trabajo. No se encontró asociación entre el consumo de benzodiazepines y las variables sociodemográficas entre los participantes del estudio.

DESCRIPTORES: receptores GABA-A; trabajadores; salud mental

\section{CONSUMO DE BENZODIAZEPINAS POR TRABALHADORES DE UMA EMPRESA PRIVADA}

O propósito deste estudo foi avaliar as variáveis associadas ao consumo de benzodiazepínicos em população trabalhadora de uma instituição privada da VIII Região, Chile. Este é um estudo quantitativo, transversal e correlacional. Participaram do estudo 40 trabalhadores de uma empresa privada da VIII Região, Chile. Para coleta dos dados utilizou-se um questionário com informações relacionadas às variáveis sóciodemográficas e Questionário de benzodiazepínicos. Não foi identificado consumo de benzodiazepínicos no momento do estudo. Constatou-se que $20 \%$ dos entrevistados tinham antecedentes de consumo de benzodiazepínicos e, destes, a metade (10\%), no último ano. A análise bivariada do consumo de benzodiazepínicos no último ano com variáveis relacionadas ao trabalho mostrou uma relação pouco significativa $(p=0,073)$ com jornada de trabalho. Não foi identificada associação entre o consumo de benzodiazepínicos e as variáveis sócio-demográficas entre os participantes deste estudo.

DESCRITORES: receptores de GABA-A; trabalhadores; saúde mental

${ }^{1}$ Obstetrical nurse, M.Sc. in Nursing, Assistant Professor, University of Concepción, Nursing Department, Chile, e-mail alisalaz@udec.cl; ${ }^{2}$ RN, PhD, Professor, University of São Paulo at Ribeirão Preto, College of Nursing, WHO Collaborating Centre for Nursing Research Development, Brazil, e-mail: amiasso@eerp.usp.br 


\section{INTRODUCTION}

In Chile, drug reports on workers shows that the consumption rates of medical drugs like tranquilizers and sedatives are higher in working people than in the general population (3.59 versus 3.29 for tranquilizers and 0.04 versus 0.03 for sedatives), according to prevalence rates reported in literature $^{(1)}$.

The category "medical drugs" contains substances whose consumption is improper without a medical prescription, such as benzodiazepinic tranquilizers (Clonazepam, Rivotril or Valpax; Alprazolam, Zotran or Ativan; Lorazepam or Amparax; Valium or Diazepam; Clorodiacepoxide; Bromacepam; Dormonit or Midazolam; Zopiclona; Zolpidem or Somno and Rohypnol) ${ }^{(1)}$. These drugs, in the market since the 1960s, are characterized by their anxiolytic (in low doses) and hypnotic sedative effect when taken in high doses, besides having myorelaxing and anticonvulsant properties $^{(2-3)}$. Nowadays, they are the most consumed drugs in the world ${ }^{(4)}$.

Internationally, studies about the consumption of benzodiazepines in the workplace are not new. Throughout the last decades, many studies have focused on the association between the use of psychotropic drugs and their relation with some work variables. Unfortunately, the results tend to be inconsistent, due to differences in general methodology, and also in how the variables were measured ${ }^{(5)}$.

In Chile, the problem of drugs in the workplace is not visible enough, having never been widely and systematically considered ${ }^{(1)}$. Therefore, it is hard to find studies that extensively investigate some variables associated to the consumption of drugs, particularly the consumption of benzodiazepine among workers. The report on the use of drugs in Chile's ${ }^{(1)}$ working population shows that the improper use of tranquilizers among working people can be found in all ages, and is significantly higher in the higher socioeconomic level (5.22\%).

Some risk factors should be taken into consideration when analyzing variables associated with the use of drugs at work. These are: personal (physical, psychological, psychosocial) and social factors (modern lifestyle, micrographic, factors or social and cultural risk conditions, variables related to work itself and organizational variables: organizational environment or culture $)^{(1)}$.

Personal physical factors, such as gender, require special attention. There is a different consumption pattern of psychotropic drugs among men and women, favoring women when analyzing studies performed with workers ${ }^{(1,5-6)}$.

Other variables that influence consumption include education level, occupation and the condition of living alone or with someone else ${ }^{(5)}$.

On the other hand, the study of work-related variables is very interesting due to the fact that work exerts a remarkable influence on human behavior. It has caused growing interest because of the influence it has on workers' health and well-being ${ }^{(7-10)}$. Nevertheless, the analysis of drugs consumption in the Chilean population according to the kind of work, for instance, shows that the highest rate is found among people who work with another family member without receiving a salary $(16.94 \%)$, followed by employees or workers from private companies $(6.52 \%)^{(1)}$. Regarding work aspects and the consumption of benzodiazepines, work hours were associated to consumption of antidepressive agents and benzodiazepine ${ }^{(11)}$.

Other factors related to the consumption of benzodiazepines among workers mainly result from emotional reasons: family problems, mental disorders, psychosomatic diseases ${ }^{(12)}$.

Finally, the interest in addressing this matter is even more based on the fact that, according to frequent reports, drugs are chronically used without proper professional surveillance ${ }^{(2,5)}$. The improper use of benzodiazepines is related to abusive and dependence states, as described for other drugs that cause dependency. With improper indication, patients who use these drugs may increase the dosage without telling the physician, among other reasons, due to the tolerance the organism develops ${ }^{(13)}$.

The aforementioned antecedents show that the use of benzodiazepines has become a greater concern for health providers and political authorities. Besides, there are investigations within the professional world that expose the consumption of benzodiazepines in recent occupational accidents ${ }^{(14-15)}$.

So, the study of this problem is based on the importance of determining the consumption of 
benzodiazepines among workers. This research tries to evaluate the magnitude and some biological, sociological and demographic variables associated to benzodiazepine consumption, due to the possible impact of chronic benzodiazepine use on workers' health, productivity and risk of accidents at work.

\section{OBJECTIVE}

The purpose of this study was to identify the variables associated with the consumption of benzodiazepines among the working population of a private institution in the Comuna de Concepción, Chile.

\section{METHODS}

The study design was quantitative, crosssectional and correlation.

The study sample included 40 people from a private company in the VIII Region that complied with the inclusion criteria: individuals between 1865 years old, officially working at the company (workers with a temporary contract were excluded), workers who were not on medical leave when using the tool and who had confirmed their consent to participate in the investigation.

Data collection tools: a questionnaire with sociodemographic variables, elaborated by the authors to collect information demographicfrom the study participants which can be associated to the consumption of benzodiazepines, and also a benzodiazepine ${ }^{(13)}$ questionnaire adapted for this investigation.

Methodology: the data were compiled after authorization by the research institution. There was a pilot test to determine the degree of comprehension of the tools, involving ten individuals from different company sectors who were present and available to answer the questionnaire on the day set for the pilot test. Since the interviewees did not present any difficulties to understand the tools, the data from the pilot study was included in the study results.

The data was processed with the statistical program SPSS 12.0. The statistical analysis used descriptive statistics and Chi-square bivariate statistical analysis. P values under 0.05 were considered statistically significant.

\section{RESULTS}

The sociodemographic data of the study population studied are presented in Table 1.

Table 1 - Sociodemographic characteristics of workers from a private institution, VIII Region. Chile 2006

\begin{tabular}{|c|c|c|}
\hline VARIABLES & $\begin{array}{c}f \\
N=40\end{array}$ & $\%$ \\
\hline \multicolumn{3}{|l|}{ Gender } \\
\hline Female & 34 & 85.0 \\
\hline Male & 06 & 15.0 \\
\hline Age $\bar{\chi}=35,4 \quad \mathrm{DT}=11.5 \operatorname{Min} 18 \operatorname{Max} 65$ & & \\
\hline 18 - 39 years old & 28 & 70.0 \\
\hline $40-59$ years old & 09 & 22.5 \\
\hline Over 60 years old & 03 & 7.5 \\
\hline \multicolumn{3}{|l|}{ Education } \\
\hline$\leq 8$ years old & 06 & 15.0 \\
\hline $9-12$ years old & 24 & 60.0 \\
\hline$\geq 12$ years old & 10 & 25.0 \\
\hline \multicolumn{3}{|l|}{ Marital Status } \\
\hline Married & 26 & 65.0 \\
\hline Single & 13 & 32.5 \\
\hline Divorced & 01 & 2.5 \\
\hline \multicolumn{3}{|l|}{ Family Structure } \\
\hline With a partner & 31 & 77.5 \\
\hline Without a partner & 09 & 22.5 \\
\hline Number of people living at home $\bar{\chi}=4,5 \mathrm{DT}=1.7$ & & \\
\hline$\leq 3$ & 10 & 25.0 \\
\hline 4 to 6 & 25 & 62.5 \\
\hline$\geq 7$ & 05 & 12.5 \\
\hline \multicolumn{3}{|l|}{ Responsible for taking care of someone at home } \\
\hline YES & 12 & 30.0 \\
\hline NO & 28 & 70.0 \\
\hline \multicolumn{3}{|l|}{ Health condition of the cared person $\mathrm{N}=12$} \\
\hline Healthy & 06 & 50.0 \\
\hline Sick & 06 & 50.0 \\
\hline
\end{tabular}

It was observed that most of the study participants are female ( $85 \%)$, married (65\%), between 18-39 years old (70\%) and with 9-12 years of education (60\%) (Table 1 ).

Table 2 presents data about the work they performed. 
Table 2 - Characteristics of work performed by workers from a private institution, VIII Region. Chile 2006

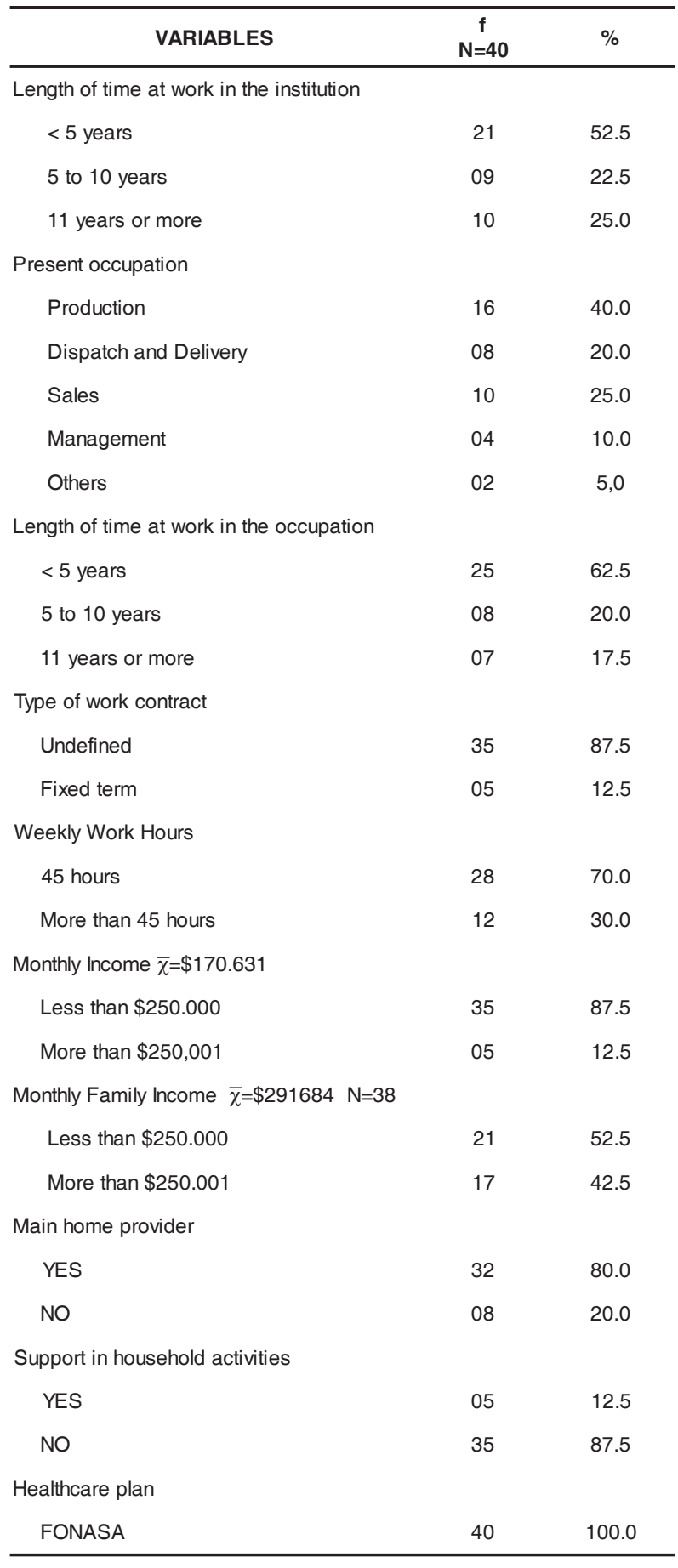

Most of the study participants had been working at the institution for less than five years $(52.5 \%)$, on a work contract without an indicated period $(87.5 \%)$ and weekly workload of 45 hours $(70.0 \%)$. A higher percentage of workers who perform activities in the production area was observed, (40\%) and most of them had been working at the institution for less than five years in the present occupation (62.5\%). The table above shows that $80 \%$ of workers in this study are the main providers for their families and have a monthly family income of less than $\$ 250,000$. Although most of the investigated professionals are female, $87.5 \%$ of the study participants did have a maid or another person to help them with household chores (Table 2).

Table 3 presents the consumption of benzodiazepine in the study population.

Table 3 - Consumption of benzodiazepine in workers from a private institution, VIII Region. Chile 2006

\begin{tabular}{lccccccc}
\hline \multicolumn{1}{l}{$\begin{array}{c}\text { Benzodiazepine } \\
\text { consumption }\end{array}$} & General & \multicolumn{3}{c}{$\begin{array}{c}\text { With a } \\
\text { prescription }\end{array}$} & \multicolumn{2}{c}{$\begin{array}{c}\text { Without a } \\
\text { prescription }\end{array}$} \\
& $\boldsymbol{f}$ & $\%$ & $\boldsymbol{f}$ & $\%$ & $\boldsymbol{f}$ & $\%$ \\
\hline Never & 32 & 80.0 & 33 & 82.5 & 39 & 97.5 \\
Last year & 04 & 10.0 & 03 & 7.5 & 01 & 2.5 \\
More than a year ago & 04 & 10.0 & 04 & 10.0 & 00 & 00 \\
\hline
\end{tabular}

There were no records of benzodiazepine consumption by the interviewees at the time of study. However, $20 \%$ of the interviewees had consumed benzodiazepine previously and $10 \%$ in the previous year.

The diagnoses associated to the consumption of benzodiazepine were, according to the interviewees: depressive disorders, (3), anxiety (2), insomnia (2) and stress (1).

The drug was prescribed by a general physician (3), psychiatrist (1) or another specialist (3). One individual mentioned having consumed benzodiazepine without medical prescription. The time of consumption was at least one and at most six months.

The reasons to cease consumption were: doctor ceasing prescription (2), patient feeling well (4) and considering it unnecessary (1).

The minimum age for the first benzodiazepine consumption was 13 years old, and the maximum was 61 .

A significantly weak relation between the consumption of benzodiazepine in the previous year and working more than 45 hours per week $(p=0.073)$ was found when relating sociodemographic variables to the consumption of benzodiazepines in the last year of the study population. 


\section{DISCUSSION}

Regarding the consumption of benzodiazepines, no present consumption was registered. $20 \%$ of workers said they had consumed it before, with $10 \%$ of these interviewees having consumed benzodiazepine in the last year. This figure is similar to other studies in Chile about this consumption in the work environment ${ }^{(11)}$.

Numbers slightly higher were reported to the Confederação de Trabalhadores do Comércio [CORSAPS] in $1997^{(12)}$. It showed that two out of ten employees had consumed tranquilizers during the last year, mostly by themselves. The interviewees argued that reasons for doing so are mostly emotional: family problems, mental illnesses, psychosomatic diseases.

It is important to state that, according to the authors, there is probably some distorted information regarding the consumption of benzodiazepines, due to the fact that individuals could have hidden information about the intake of this drug, because consuming tranquilizers generally has a negative social value in the professional world ${ }^{(1)}$.

They tried to control this aspect by explaining to the participants that the information would be kept anonymous and confidential, and that it would be used exclusively to contribute to the implementation of work-related healthcare promotion and prevention programs. However, one cannot say that they omitted information about consumption, especially without medical prescription. On the other hand, some individuals had problems when identifying whether some drugs they were taking were benzodiazepines or tranquilizers, probably due to their low level of instruction.

In this study, the diagnoses that originated the use of benzodiazepines, as described by the interviewees, were: depressive disturbances, anxiety, insomnia and stress. They coincide with other studies regarding health conditions associated with the prescription of benzodiazepines ${ }^{(11,13)}$.

A slightly significant relation was found $(p=0.073)$ between the consumption of benzodiazepines in the last year and working over 45 hours when these biosocial demographic variables of benzodiazepine consumption were related in the study population in the last year. It is important to mention that, according to the 2005 labor legislation in Chile, the work week consists of 45 hours $^{(16)}$. Although this relation has no significant results in the present research, other studies proved there was a relation. Chilean research about teachers' mental health showed that teachers who worked more hours mentioned consuming antidepressive agents and benzodiazepines more often in the last two years, visiting a psychiatrist in the last two years and receiving a diagnosis of depressive disorder once in their lives ${ }^{(11)}$.

Similarly, one of the variables that were more frequently associated to the deterioration of physical and mental health is long hours at work. A study on the potential effects on health and performance of extended work day concluded that there is enough evidence to support concerns about the health risks and security that long working hours imply ${ }^{(8)}$. Studies of quantitative and qualitative reviews regarding the effects of working hours on health showed significant correlations among global health symptoms, physiological and psychological health symptoms and work hours ${ }^{(7)}$.

The previous factors regarding the relation between the consumption of benzodiazepines and working overtime every week, according to the rules in effect, draws everybody's attention. This relation should be further explored in a larger population. This would contribute to overcome the addition problems of Chi-square, present when working with a small number of individuals.

Finally, according to the authors, f further analysis of these data is necessary, using a multivariate exploratory technical analysis, such as correspondence analysis. This could evidence the relation among the categories of each variable separately and the relation among categories of both variables simultaneously. Also, this could generate perception maps in order to graphically represent the structure of relations among two or more qualitative study variables ${ }^{(17)}$

\section{ACKNOWLEDGEMENTS}

Acknowledgements to the Inter-American Drug Abuse Control Commission/CICAD of the SubSecretary of Multidimensional Security at the Organization of American States/OAS, the Brazilian Anti-Drugs Secretary/SENAD, faculty members at the University of São Paulo at Ribeirão Preto College of Nursing, WHO Collaborating Centre for Nursing 
Research Development, Brazil, to the population who participated in the studies and to the representatives from eight Latin-American countries who participated in the I and II On-Line Specialization Program for
Research Capacity-Building on the Drugs Phenomenon-PREINVEST, offered in 2005/2006 by the University of São Paulo at Ribeirão Preto College of Nursing, as a distance education course.

\section{REFERENCES}

1. Consejo Nacional para el Control de Estupefacientes. [homepage on the Internet]. Chile: Informe sobre uso de drogas en la población laboral. [Tener acceso en el 28 de agosto 2006]. Disponible en URL:http:// www.conacedrogas.cl/pdf

2. Silva L, Vergara E, Yera I, Feijoso, E. Utilización de benzodiazepinas en la Atención Primaria de Salud. Rev Cubana Med Gen Integr 2002; 18(3).

3. Kaplan H, Sadock B. Sinopsis de Psiquiatría. 8. ed. Madrid (España): Editoral Médica Panamericana, Williams y Wilkins; 2000. 1589p.

4. Poyares D, Ribeiro LJ, Tavares S, Barros-Vieira S. Hipnoindutores e insônia. Rev Bras Psiquiatr 2005; 27(1):2-7. 5. Pelfrenea E, Vlerickb P, Moreauc M, Maka RP, Kornitzerc M, De Backera G. Use of benzodiazepine drugs and perceived job stress in a cohortof working men and women in Belgium. Results from the Belstress-study. Soc Sci Med 2004; 59:433-42.

6. Rojas M. Mujeres que consumen sustancias psicoactivas. Centro de Información y Educación para la Prevención y Abuso de Rogas. Lima (Perú): 1999.

7. Sparks K, Cooper C, Fried, Y, Shiron, A. The effects of weekly work on health: A meta-analytic review. Occup Org Psychol 1997; 70: 391.

8. Spurgeon A, Harrington JM, Cooper C. Health and safety problems associated with long working hours: A review of the current position. Occup Environ Med 1997; 54 (6): 367-9. 9. Paschoal T, Tamayo A. Validação da Escala de Estresse no Trabalho. Estudos de Psicologia 2004; 9: 45-52.
10. Espinosa M. Calidad de vida en le trabajo: reflexiones en torno a la inseguridad y el malestar social In Departamento de Estudios, Dirección del Trabajo: Temas Laborales No 18, Santiago de Chile; 2001. [Tener acceso en el 26 de novembro 2006]. Disponible en URL: http://66.102.7.104/ search?q=cache: wopKuB3 vyQAJ:www.dt.gob.cl/ documentacion/1612/articles61006_temalab_18.pdf+temas+ laborales $+\mathrm{N} \% \mathrm{C} 2 \% \mathrm{~B} 018 \& \mathrm{hl}=\mathrm{es} \& \mathrm{gl}=\mathrm{cl} \& \mathrm{ct}=\mathrm{clnk} \& \mathrm{~cd}=1$

11. Claro S, Bedregal P. Aproximación al estado de salud mental del profesorado en 12 escuelas de Puente Alto, Santiago, Chile. Rev Méd Chile 2003; 131(2): 159-67.

12. Corporación de Salud y Políticas Sociales [CORSAPS] Confederación Nacional de Sindicatos y Federaciones de Trabajadores del Comercio, Confección de Vestuario y Actividades Conexas [CONSFECOVE]. Uso de Benzodiazepinas en Trabajadores del Comercio de Santiago. 1996.

13. Galleguillos T, Risco L, Garay JL, González M, Vogel M. Tendencia del uso de benzodiazepinas en una muestra de consultantes en atención primaria. Rev Méd Chile 2003; 131: 535-40.

14. Trucco M, Rebolledo P, González X, Correa A, Bustamante $M$. Consumo reciente de alcohol y drogas en accidentes del trabajo. Revista Médica de Chile 1998; 126:1262-7.

15. O'Neill D. Benzodiazepines and driver safety. Lancet 1998; 352 (9137):1324-2.

16. Gobierno de Chile. Dirección del Trabajo Gobierno de Chile. [homepage on the Internet]. Chile: Nueva Jornada de trabajo semanal. [Tener acceso en el 23 de novembro 2006]. Disponible en URL: http://www.dt.gob.cl/1601/article72784.html

17. Vivanco M. Análisis Estadístico Multivariante. Santiago (Chile): Universitaria; 1999. 